\title{
Improving Student's Concept Understanding on Equilibrium of a Rigid Body Subject with the Applying of Physics Education and Technology
}

\author{
Septina Severina Lumbantobing*, Manogari Sianturi and Ganti riang Somasi Manao
}

Physics Education, Faculty of Teacher Training and Educaion, Universitas Kristen Indonesia

Corresponding Email: septinaseverina@gmail.com

\begin{abstract}
This research was conducted to get a picture of improving concept understanding of students who get equilibrium of a rigid body subject in senior high schools with applying of PhET (Physics Education and Technology. The study was conducted using quasi-experimental methods with randomized one group pretest - posttest design. The population is all grade XI students of SMA Negeri 42 Jakarta. A sample of one class was selected by cluster random sampling. The sample of this research was class XI A with 32 students. Test instruments in the form of multiple choice tests were 18 items with 5 options answer. The data is processed with the help of SPSS 22 software. The results showed that there was an increase in students' concept understanding with a gain value of 0.60 in the medium category.
\end{abstract}

Keywords: concept understanding, PhET

\section{INTRODUCTION}

To face up Industrial Revolution 4.0 era, human resources who have the ability to think, which include logical reasoning, critical, creative, are able to communicate ideas, especially in solving problems (Kemendikbud, 2013). School institutions are obliged to prepare students to be able to adapt to the needs and developments of the age so that they are able to compete in the future. One way that the government has done is to apply the 2013 curriculum in every school in Indonesia. In the 2013 curriculum learning is designed with a scientific approach where students are required to be able to develop their scientific abilities. Therefore teachers are required to create creative, innovative learning situations with learning aids namely appropriate and effective learning media.

Teachers as educators must be able to develop learning media in accordance with the curriculum, the development of student needs, and the development of information technology. Teachers must prepare students to be able to follow technological developments because now almost all aspects of human life are inseparable from the use of technology. If in the past we wanted to shop or order plane tickets we had to make direct transactions, now we can do it only through various online shopping applications. The work of the pot filler will disappear because the aluminum pan is replaced by stainless steel. Bank tellers and travel services are also slowly but surely disappearing. Many more jobs are ready to disappear and will be replaced by robots and artificial intelligence. Therefore, schools through teachers must prepare students to have the ability to adapt to developments in the era of the Industrial Revolution 4.0. Therefore, schools through teachers must prepare students to have the ability to adapt to developments in the era of the Industrial Revolution 4.0. One of the principles in the learning process standard is the use of information and communication technology to improve the efficiency and effectiveness of learning (Permendikbud, 2014). Eggen \& Kauchak (2012) state that using technology is highly emphasized in today's education.

Media is anything that can be used to channel messages from the sender to the recipient so that it can stimulate the thoughts, feelings, attention, and interests and attention of students so that the learning process occurs. (Sadiman, 2010). The use of instructional media will provide many benefits as explained by Sudjana (2013), namely learning will attract the attention of students so that it can foster motivation to learn, the lesson material will be more clear in meaning so that students can better 
understand and allow students to master the learning goals with better, more varied teaching methods not only verbal communication that is through speaking of words by educators, so that students do not get bored and educators do not run out of energy, and students do a lot of learning activities not only listen to educators' descriptions but do various learning activities such as observing, do, demonstrate and others.

The learning process that takes place without the use of instructional media that can visualize abstract processes that cannot be seen directly by the eyes of students will result in a lack of understanding of students' concepts so that students only guess what they are learning. Concept understanding is the ability to understand existing understandings such as being able to convey or express a material presented in a simpler form so that it is more easily understood by others, able to provide interpretations and be able to apply it in a simple form. Understanding the concept is important for students because it will help students in linking various material being studied so that memorizing formulas is not the only way to solve problems. With a good understanding of the concept, students will be able to apply the subject matter in real events in everyday life. If the understanding of the concepts of relevant learning materials is still lacking, students will tend to experience difficulties in solving problems.

Physics Education Technology (PhET) is a simulation developed by the University of Colorado which contains simulations of physics learning for the benefit of classroom learning or individual learning. PhET simulations emphasize the relationship between real life phenomena and the underlying science, support learning with interactive approaches and constructivism, provide feedback, and provide a creative workplace (Finkelstein, 2006). PhET simulations present research-based physical phenomena. This simulation makes it easy for students to learn physics concepts. PhET simulations are packaged like games / games so students can explore physics material with more fun. With learning packaged in the form of Physics Education Technologies (PhET) simulations it will create new experiences for students and help improve conceptual understanding of physics subject matter. This PhET simulation was chosen because this simulation is based on a java program which has the advantage of easy java simulation (ejs) specifically designed to facilitate the task of teachers in making physics simulations by utilizing computers in accordance with their fields. (Sunni et al, 2014).

PhET simulation media, if reviewed based on the cone of Edgar Dale's experience (Dale's Cone of Experience), then this media is included in the level the most concrete, where students $90 \%$ will actively involved in observing learning activities, do an experiment, and conclude that data was obtained. PhET simulation media about equilibrium of a rigid body presents a visualization of the equilibrium of objects in everyday life. Through a PhET simulation system that can be made by yourself by students so that they can conduct experiments and observations to understand the equilibrium of a rigid body.

In research conducted by Perkins et al. (2006) suggested that the benefits PhET simulation for student learning was obtained, $62 \%$ stated that the simulation very useful for them. PhET simulation learning has stimulated students' knowledge and understanding rather than conventional learning. This is evident from previous studies that there were $81 \%$ of experimental class students who used PhET simulations in the learning process of answering correctly and $64 \%$ of students answering correctly for other classes without using a PhET simulation (Ajredini, Izairi, \& Zajkov, 2013).

Based on the background of the problems outlined above, the purpose of this study is to find out "how to increase students' understanding of concepts for the subject of rigid body equilibrium after obtaining a learning approach assisted with Physics Education Technologies (PhET) simulation media?

\section{METHODS}

In this study the method used was a quasiexperimental design using a randomized one group pretest-posttest design (Arikunto, 2013). This research was conducted at 42 Jakarta High School in the 2019/2020 school year. The population in this study were all students of class XI, amounting to 5 classes. The sampling technique is cluster random sampling, in which the study sample is class XI A.

Table 1: Research design

\begin{tabular}{lll}
\hline \multicolumn{1}{l}{ Pretest } & Treatment & Posttest \\
\cline { 2 - 3 } $\mathrm{T}_{1}$ & $\mathrm{X}$ & $\mathrm{T}_{2}$ \\
Information: & \\
$\mathrm{T}_{1} \quad=$ Test before treatment \\
$\mathrm{X} \quad=$ Treatment in the form of applying the PhET \\
$\mathrm{T} \quad=$ Test after treatment
\end{tabular}

The instruments in this study consisted of test instruments. The test instrument is in the form of a concept understanding test in the form of a multiple choice test of 18 items with 5 answer choices. The concept understanding test consists of 3 aspects 
namely, translation (ability to translate), interpretation (ability to interpret) and extrapolation (ability to predict). The test consisted of 18 items divided into 6 items for each aspect of concept understanding. Provision of tests carried out 2 times, namely pretest and posttest. Pretest is given before class given treatment with the aim of knowing students' understanding of the initial concepts. Then the class is given treatment by applying the learning approach to the PhET simulation media. After the class is given treatment then given a posttest to see how much improvement in understanding students' concepts.

The analysis technique used in this study to calculate how much increased understanding of concepts after learning with the PhET simulation media was obtained by calculating the average value of the normalized gain / N-gain (Hake, 1999) used, namely:

$$
g=\frac{\text { score posttest }- \text { score pretest }}{\text { score max }- \text { score pretest }}
$$

with $(<\mathrm{g}>)<0.3$ in the low category; $0.3 \leq(<\mathrm{g}>)<0.7$ moderate category; and $(<\mathrm{g}>) \geq 0.7$ with the high category.

\section{RESULT AND DISCUSSION}

The purpose of this study is to see an increase in students' understanding of concepts after applying learning to the simulation media PhET. Data on the results of increasing understanding of concepts was obtained from the pretest and posttest scores. The average score of pretest, posttest, and average normalized gain $\langle\mathrm{g}\rangle$ can be seen in Table 2

Table 2: Pretest and Posttest Result for Concept Understanding

\begin{tabular}{|l|l|l|}
\hline & Pretest & Posttest \\
\hline Mean & 49.84 & 80.13 \\
\hline Median & 50.00 & 83,00 \\
\hline Minimum & 33.00 & 56.00 \\
\hline Maximum & 67.00 & 94.00 \\
\hline Std Deviasi & 10.96 & 10.03 \\
\hline
\end{tabular}

Table 2. shows the average score of the initial test (pretest) and the average score of the final test (posttest) understanding the concepts achieved by students before applying learning with the media simulation of PhET. The average pretest scores of students before learning were 49.84. This shows that students' understanding of concepts is still very low. The low score of students' pretests is due to several factors including more students doing conventional learning activities such as doing exercises in textbooks, re-writing lessons from the blackboard and the teacher is still the most important source of learning. In addition, students are also rarely trained in the ability to understand concepts so that when asked to do problems in the form of problem solving (problem solving), students can not do well. As a result of this way of learning, it can be seen the minimum score of students at the time of the pretest is at 33.00 and the maximum score is only 67.00.

The average posttest score of students' understanding after treatment increased to 80.13. This is because the learning process of students in the class has changed from teacher center learning to student centered learning. When learning in class students no longer only listen and take notes but students must also take part in conducting learning activities. During the learning process, subject matter is delivered not only through lecture activities but also using the help of a PhET simulation media. By using a PhET simulation, the delivery of subject matter is no longer abstract but real or real. When students observe and do simulations with PhET media, curiosity arises from within students. It is through this curiosity that questions arise from students. Submitting questions and gathering information to find answers or solutions to these questions becomes an effective learning tool that can train students' understanding of concepts. The effect of the application of the PhET simulation media carried out in the classroom is very effective, it can be seen an increase in the student's minimum score when the posttest rises to 56.00 and the maximum value reaches 94.00 .

To see an increase in students' overall understanding of the concept used by calculating the average normalized gain value $\langle\mathrm{g}\rangle$ from the student's pretest and posttest data as in the table 3 .

Table 3. Normalized Gain Value $\langle\mathrm{g}>$

\begin{tabular}{|l|l|l|l|l|}
\hline & Pretest & Posttest & Gain Score & Criteria \\
\hline Sampel & 49.84 & 80.13 & 0,60 & Moderate \\
\hline
\end{tabular}

From table 3 we can see that increasing students' understanding of concepts is in the medium category. Increasing students' understanding of concepts cannot reach high criteria due to several factors. First, students are not familiar with learning to use PhET simulation media, so they still need adjustments. Students are still often wrong in running a PhET simulation media program that results in the results obtained are not optimal. These constraints cause the learning process in the class has not run smoothly. Both students are also new in terms of solving problems in the learning process because they are already familiar with the activity of taking notes and just listening without doing simulations or experiments. 
To see an improvement in every aspect of concept understanding which consists of translation, interpretation and extrapolation can be seen in figure 1 .

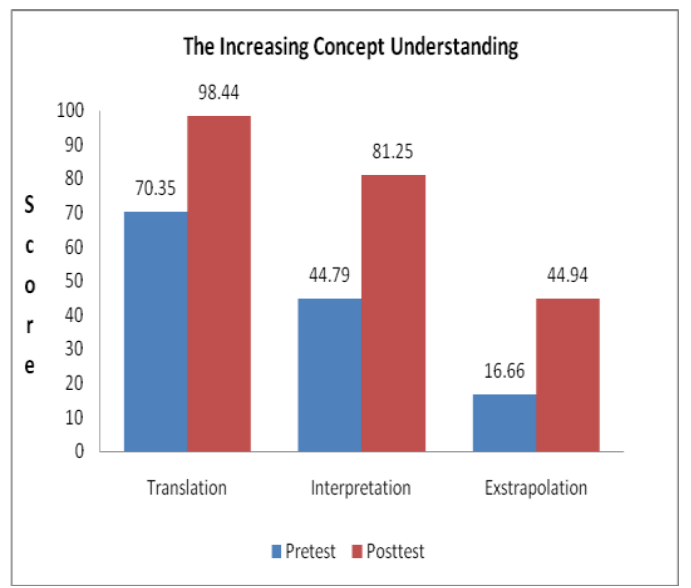

Figure 1. Average Student Scores in Every Aspect of Concepts Understanding.

From Figure 1 it can be seen that the students' posttest results are increasing in every aspect of concept understanding. The highest aspect of concept understanding is the improvement in the realm of translation with an average value of 98.44. This is because in the realm of translation, students are only required to be able to translate or change certain symbols into other symbols without any change in meaning. For the realm of interpretation is in the high category with an average value of 81.25 . In this realm, students are required to be able to interpret or explain the meaning or concept contained in the symbol by comparing, differentiating or contrasting it with something else so that there is no change in the meaning of the symbol. PhET simulation media with the help of animation and games help students in interpreting activities because they can observe experiments directly so that learning is more tangible.

For the extrapolation domain, the lowest increment is in the medium category with an average value of 44.94, this is because in the extrapolation aspect students are required to be able to predict or see the direction tendency of a finding. In this realm requires higher intellectual abilities so that this domain is in the medium category. To train students' intellectual abilities, the use of PhET simulations is packaged like a game / game so students can explore physics material more fun. With learning that is packaged in the form of Physics Education Technologies (PhET) simulations will create new experiences for students and help improve conceptual understanding of physics subject matter even though students do not conduct experiments in real. Simulation media are also very helpful for students to understand abstract concepts through animation provided by PhET. Although the increase in extrapolation aspects experienced the lowest increase, this shows a positive result because there was an increase from the low to the medium category after the treatment of PhET simulation media was given.

\section{CONCLUSION}

Based on the results of research and data analysis that has been done regarding the application of PhET simulation media in learning, it can be concluded that this learning can further enhance students' understanding of concepts with a gain value of 0.60 in the medium category.

\section{REFERENCES}

1. Ajredini, F., Izairi, N., \& Zajkov, O., 2013. Real Experiments versus PhET Simulations for Better High-School Students' Understanding of Electrostatic Charging. European J of Physics Education, 5(1), 1-12.

2. Arikunto, Suharsimi., 2013. Dasar-Dasar Evaluasi Pendidikan. Jakarta : Bumi Aksara.

3. Eggen, P. \& Kauchak, D., 2012. Strategi dan Model Pembelajaran: Mengajarkan Konten dan Ketrampilan Berpikir edisi ke enam. Terjemahan: Satrio Wahono. Jakarta: Permata Puri Media. Boston: Pearson Education.

4. Fraenkelstein, Jack R \& Norman, Wallen., 2006. How to Design and EvaluateResearch in Education. New York : Mc Graw Hill.

5. Hake, R. R., 1999. Analyzing Change/Gain Score. AREA-D American education Research Association's Devision Measurement and Research Methodology

6. Kemendikbud., 2013. Pengembangan Kurikulum 2013. Paparan Mendikbud dalam Sosialisasi Kurikulum. Jakarta: Kemendikbud.

7. Perkins, et al., 2006. PhET: Interactive Simulations for Teaching and Learning Physics. Journal The Physics Teacher. Vol. 44.

8. Permendikbud, 2014. Peraturan Menteri Pendidikan dan Kebudayaan No. 103 Tahun 2014 pasal 2 ayat 7 dan 8 tentang Pembelajaran Pada Pendidikan Dasar dan Pendidikan Menengah.

9. Sadiman, et al., 2010. Media Pendidikan. Jakarta: Raja Grapindo Persada.

10. Sudjana, Nana., 2013. Dasar-Dasar Proses Belajar Mengajar. Bandung: Sinar Baru Algesindo. 
11. Sunni, M.A., Wartono, \& Diantoro, M., 2014.

Pengaruh Pembelajaran Problem Solving Berbantuan PhET Terhadap Penguasaan Konsep Fisika Dan Kemampuan Berpikir Kritis Siswa SMA. Malang: Pasca Sarjana Universitas Negeri Malang 